\title{
Ovarian steroid metabolism during post-natal development in the normal mouse and in the adult hypogonadal ( hpg) mouse
}

\author{
M. A. Mannan and P. J. O’Shaughnessy \\ Department of Anatomy, Royal Veterinary College, Royal College St, London NWI OTU, U.K.
}

\begin{abstract}
Summary. Ovarian steroid metabolism was investigated (i) during development in a normal inbred strain in which post-natal follicle growth has been described and (ii) in adult hypogonadal ( $h p g$ ) mice which lack GnRH and have very low serum concentrations of gonadotrophins. Tissue was incubated with $\left[{ }^{3} \mathrm{H}\right]$ pregnenolone or $\left[{ }^{3} \mathrm{H}\right]$ androstenedione and metabolites separated by t.l.c. or h.p.l.c. Progesterone was the major metabolite formed at all ages while androstenedione was the major androgen. Between 7 and 21 days there was an overall increase in steroidogenic enzyme activity with a peak of $5 \alpha$-reductase between 21 and 29 days. The major metabolite of progesterone around puberty was $5 \alpha$-pregnane-3 $\alpha$-ol-20-one. A sharp increase in $20 \alpha-$ hydroxysteroid dehydrogenase was observed after 38 days due, presumably, to the appearance of corpora lutea. Unlike the rat, androstanediol levels were low at all ages. Oestradiol was the major oestrogen formed from androstenedione with a peak of production at 38 days. In the adult hpg mouse metabolism was similar to that of the 7-day normal mouse although 17-ketosteroid reductase and aromatase levels were very low compared to normal animals of any age, indicating that gonadotrophin stimulation is involved in the expression of activity by these enzymes.
\end{abstract}

Keywords: mouse; ovary; development; steroidogenesis; hypogonadal

\section{Introduction}

Ovarian steroid metabolism during development in the rat has been studied in several laboratories by measuring the metabolites formed from exogenous tritiated progesterone (Eckstein et al., 1976; Karakawa et al., 1976; Eckstein \& Ravid, 1979; Uilenbroek et al., 1983; Cohen et al., 1984). In contrast, few studies have been carried out to examine steroidogenesis in the mouse ovary although this animal offers distinct advantages in the study of ovarian development. These advantages include the post-natal formation of primordial follicles and the availability of strains with specific mutations which affect the reproductive system. Kraiem \& Samuels (1974) have measured changes in the activity of some steroidogenic enzymes in the ovaries of 25-day-old animals after gonadotrophin treatment. In this study we have examined changes in the overall pattern of steroid metabolism in the mouse ovary during development using a mouse strain in which the pattern of post-natal follicular development is known (Halpin et al., 1986). We have developed a combination of thin-layer chromatography (t.l.c.) and high-performance liquid chromatography (h.p.l.c.) which separates more than 25 different gonadal steroids and allows use of $\left[{ }^{3} \mathrm{H}\right]$ pregnenolone as substrate, one step earlier in the steroidogenic pathway than progesterone. In addition to studying the pattern of development in the normal animal we have examined steroidogenesis in the adult hypogonadal ( $h p g$ ) mouse. The hypogonadal ( $h p g)$ mouse lacks hypothalamic GnRH and is grossly deficient in pituitary and serum gonadotrophins which leads to severe hypogonadism (Cattanach 
et al., 1977). The ovaries are capable of developing preovulatory follicles and fertile ova on transplantation into normal animals and therefore behave normally under the appropriate hormone stimulus. The hpg female is therefore ideal for the study of gonadotrophin control of ovarian function and for the determination of which components of the normal steroidogenic pattern are gonadotrophin-dependent.

\section{Materials and Methods}

\section{Animals}

The mice used in this study were normal or hpg animals reared in the Department of Anatomy, Royal Veterinary College, London, from breeding stock provided by Dr H. M. Charlton, Department of Human Anatomy, Oxford. The animals were derived originally from $\mathrm{F}_{1}$ hybrids of two inbred strains $\mathrm{C} 3 \mathrm{H} / \mathrm{HeH}$ and $101 / \mathrm{H}$ (Cattanach et al., 1977). The day of birth was designated as Day 0 and animals were used for experiment when aged 7, 21, 29, 38 and 60 days, ages previously used for morphological studies in this strain (Halpin et al., 1986).

\section{Materials}

The radioactive steroids $\left[4,7-{ }^{3} \mathrm{H}\right]$ pregnenolone, $\left[1,2,6,7,-{ }^{3} \mathrm{H}\right]$ androstenedione, $\left[4-{ }^{14} \mathrm{C}\right]$ testosterone, $\left[4-{ }^{14} \mathrm{C}\right]-$ androstenedione, $\left[4-{ }^{14} \mathrm{C}\right]$ progesterone, $\left[4-{ }^{14} \mathrm{C}\right]$ oestradiol, $\left[4-{ }^{14} \mathrm{C}\right] 5 \alpha$-dihydrotestosterone (DHT) and $\left[4-{ }^{14} \mathrm{C}\right] 17 \alpha-$ hydroxyprogesterone were purchased from Amersham International Plc (Amersham, U.K.). $\left[4{ }^{14} \mathrm{C}\right]$ Pregnenolone was purchased from New England Nuclear (Du Pont (U.K.) Ltd, Hertfordshire, U.K.). Radioactive steroids were purified by t.l.c. before use. Non-radioactive steroids were purchased from Sigma Chemical Co. (Poole, Dorset, U.K.) or Steraloids Lid (Croydon, U.K.). Organic solvents were purchased from BDH (Poole, Dorset, U.K.) and culture medium from Flow Laboratories (Irvine, U.K.).

\section{Tissue incubation}

Mice were killed by decapitation and the ovaries quickly removed into cold Medium 199 containing $10 \mathrm{~mm}$ Hepes and $0.1 \% \mathrm{BSA}, \mathrm{pH} 7 \cdot 4$. The ovaries were minced using fine scissors and tissue from a single animal was then incubated in $0.5 \mathrm{ml}$ Medium 199 containing $0.5 \mu \mathrm{Ci}\left[{ }^{3} \mathrm{H}\right]$ pregnenolone $(25 \mathrm{pmol})$, added in $15 \mu \mathrm{l}$ dimethylsulphoxide. Incubations were carried out for $5 \mathrm{~h}$ at $37^{\circ} \mathrm{C}$ in an atmosphere of $5 \% \mathrm{CO}_{2}$ in air and were terminated by placing the tubes in ice. Non-radioactive, carrier steroids $(25 \mu \mathrm{g})$ and ${ }^{14} \mathrm{C}$ steroids (2000 d.p.m.), to monitor recovery, were then added to each tube. The carrier steroids normally added at this time were pregnenolone, progesterone, testosterone, androstenedione, androstenediol, 17 $\alpha$-hydroxyprogesterone, 17 $\alpha$-hydroxypregnenolone, oestradiol, oestrone and oestriol. Other standards were added just before til.c. or h.p.l.c. for visuatization. The ${ }^{14} \mathrm{C}$ steroids added were testosterone, progesterone, androstenedione, 17 $\alpha$-hydroxyprogesterone, pregnenolone, oestradiol and DHT.

\section{Steroid extraction and separation}

The medium was extracted twice with 10 volumes of ethyl acetate. The extracts were dried and partitioned into neutral and phenolic steroids as described by Hutchison et al. (1981). Steroids were then separated by a combination of t.l.c. and h.p.l.c. (Table 1).

Thin-layer chromatography. Initial separation of the neutral steroids was by t.l.c. in chloroform:ether $(7: 1 \mathrm{v} / \mathrm{v})$ using plastic-backed silica gel plates (Whatman, Maidstone, Kent, U.K.). The chromatogram was divided into 6 zones on the basis of standard steroids observed under u.v. light and by visualizing standards in control lanes using $5 \%$ phosphomolybdic acid in ethanol. Zone 1 had the highest $R_{\mathrm{F}}$ value while zone 6 represented the origin. Zones 1,2 and 3 contained $5 \alpha$-dihydroprogesterone, progesterone and androstenedione respectively. In most experiments these steroids were cut out and counted directly in a scintillation counter. In some cases progesterone was eluted and retained for h.p.l.c. as described below to determine whether $5 \alpha$-androstane-3,17-dione was present. Zone 4 (area of t.l.c. between androstenedione and testosterone) was eluted with methanol and the steroids separated by h.p.l.c. (see below). Zone 5 extended from testosterone to the origin. This area was eluted in methanol and applied to a second t.l.c. separation using chloroform:methanol $(97: 3 \mathrm{v} / \mathrm{v})$. This chromatogram was divided into 7 zones of decreasing $R_{\mathrm{F}}$ value by visualization of standard steroids. Zones 1,2,3,6 and 7 contained $17 \alpha$-hydroxyprogesterone, 20adihydroprogesterone, testosterone, $5 \alpha$-pregnane- $3 \alpha, 17 \alpha$-diol and triols and these areas were counted directly (the triols were not further separated). Zone 4 contained $17 \alpha$-hydroxypregnenolone, $5 \alpha$-pregnane- $3 \beta, 17 \alpha$-diol, $\Delta 5$ -

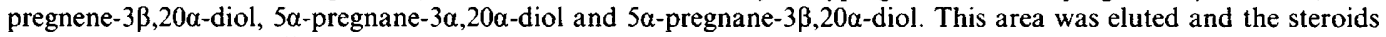
were acetylated as described previously (O'Shaughnessy et al., 1981). After acetylation steroids were separated by t.l.c.

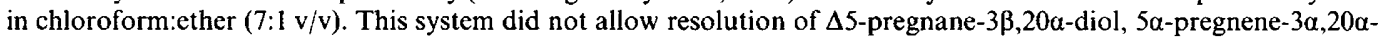

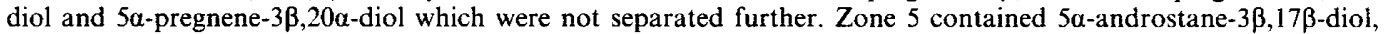
androstanediol and androstenediol and these were separated by h.p.l.c. as described below. The $\mathrm{NaOH}$ fraction was 
neutralized by $4 \mathrm{~N}-\mathrm{HCl}$ and the phenolic steroids were extracted twice with 10 volumes of ethylacetate. The dried steroids were acetylated and were separated by t.l.c. using dichloromethane:ethyl acetate (99:1 v/v) (Milewich et al., 1977). The t.l.c. plates were scanned using a radiochromatogram scanner to identify the position of radioactive metabolites. Areas representing oestrone, oestradiol and oestriol were cut out and counted directly.

High-performance liquid chromatography. Steroids were separated by h.p.l.c. using a high-pressure mixing h.p.l.c. system (Waters, Middlesex, U.K.) to pump the solvent and monitor the effluent for u.v. absorbance at $210 \mathrm{or} 240 \mathrm{~nm}$. To separate steroids from zone 4 of the first t.l.c. (chloroform:ether, 7:1 v/v) samples were injected onto a $5 \mathrm{~mm} \times 10 \mathrm{~cm}$ column packed with Hypersil ODS, $5 \mu$ (Hichrome, Reading, U.K.) and eluted with a gradient of increasing methanol concentration as shown in Fig. 1. Nine steroids were separated in this step, eluted in the order DHEA, isoandrosterone, DHT, 5 $\alpha$-pregnane-17a-ol-3,20-dione, androsterone, pregnenolone, $5 \alpha$-pregnane-20a-ol-3one, allopregnanolone and $5 \alpha$-pregnane-3 $\alpha$-ol-20-one.

To separate steroids in zone 5 of the second t.1.c. (chloroform:methanol, 97:3v/v) samples were applied to a column as above and eluted in an isocratic system of $60 \%$ methanol in water. Under these conditions steroids eluted in the order androstenediol, androstanediol and $5 \alpha$-androstane-3 $3,17 \beta$-diol. To separate progesterone from $5 \alpha$ androstane-3,20-dione, samples were applied to the same isocratic system.

The percentage recovery of steroids, after separation, was estimated using added ${ }^{14} \mathrm{C}$ standards when possible. When no ${ }^{14} \mathrm{C}$ standard was available for a particular steroid the recovery was estimated from other steroids for which a ${ }^{14} \mathrm{C}$ standard was available and which had been through the same separation procedures. After separation of steroids, representative samples of the major metabolites were recrystallized to a constant ${ }^{3} \mathrm{H} /{ }^{14} \mathrm{C}$ ratio to check purity. Metabolites formed have been expressed as a percentage of the total radioactivity added to each tube following correction for the recovery of each steroid. Data were analysed by one-way analysis of variance.

\section{Results}

The combination of t.l.c. and h.p.l.c. described here allowed separation and measurement of 25 different gonadal steroids (Table 1). Many of these steroids were not, however, formed to a significant extent from $\left[{ }^{3} \mathrm{H}\right]$ pregnenolone during incubation of ovarian tissue from mice at any of the ages examined. We have, therefore, reported primarily those metabolites which contributed $0.5 \%$ or greater of the total radioactivity at one or more of the ages examined.

Significant steroidogenic activity was present at 7 days and by 21 days the levels of activity were similar to those of the adult although the incubation conditions were not designed to measure the maximum steroidogenic ability. The effect of age on each of the metabolites reported in Table 2 was significant $(P<0.05)$ as assessed by analysis of variance. At all ages examined progesterone was the major metabolite formed (Table 2) with androstenedione the major $C_{19}$ steroid. Between 7 and 21 days there was a marked increase in the levels of progesterone, androstenedione, $5 \alpha$-dihydroprogesterone, allopregnanolone and $5 \alpha$-pregnane-3 $\alpha$-ol-20-one, suggesting an increase in activity of $3 \beta$-hydroxysteroid dehydrogenase-isomerase ( $3 \beta-\mathrm{HSD}), \mathrm{C}_{17}-\mathrm{C}_{20}$ lyase and $5 \alpha$-reductase. At 21 and 29 days, $5 \alpha$-pregnane- $3 \alpha$-ol- 20 one was the major metabolite of progesterone formed. Between 29 and 38 days there was an increase in $\mathrm{C}_{19}$ steroid production, a decrease in overall $5 \alpha$-reduced steroids and a sharp increase in $20 \alpha$-dihydroprogesterone. High $20 \alpha$-hydroxysteroid dehydrogenase (20 $\alpha$-HSD) activity and relatively low $5 \alpha$-reductase activity were also observed in the mature animal of 60 days. Amounts of androstanediol were low at all ages although a peak of production was observed at 38 days. Intermediates from the $\Delta^{5}$ pathway of androgen production were not formed to a significant extent, suggesting that this pathway is relatively unimportant in the mouse ovary.

In the experiments described above, using $\left[{ }^{3} \mathrm{H}\right]$ pregnenolone as substrate, only trace amounts of oestrogens were observed at all ages. When $\left[{ }^{3} \mathrm{H}\right]$ androstenedione was used as substrate, however, significant amounts of oestradiol were formed at all ages with a maximum at 38 days (Table 3). Oestrone was not detectable at 7 days but was present from 21 days while no other phenolic steroids, including oestriol, 16-keto oestrone or 17-epioestriol, were detected at any age.

In the ovary of the $h p g$ mouse the pattern of $\left[{ }^{3} \mathrm{H}\right]$ pregnenolone metabolism was similar to that of a 7-day animal with the exception that $20 \alpha$-dihydroprogesterone was not found and testosterone was detected in only one animal (Table 2). With $\left[{ }^{3} \mathrm{H}\right]$ androstenedione as substrate there was no significant formation of oestrone or oestradiol using ovaries from single animals although significant levels of testosterone were formed under these conditions in all animals $(3 \cdot 7 \pm 0.8 \%$ of added 
Table 1. Possible $\left[{ }^{3} \mathrm{H}\right]$ pregnenolone metabolites isolated* in this study

\begin{tabular}{|c|c|c|}
\hline \multicolumn{2}{|c|}{ Steroids } & \multirow[b]{2}{*}{$\begin{array}{l}\text { Isolation } \\
\text { procedure† }\end{array}$} \\
\hline Trivial names & $\begin{array}{l}\text { Systematic names } \\
\text { (and abbreviation) }\end{array}$ & \\
\hline $\begin{array}{l}5 \alpha \text {-Dihydroprogesterone } \\
\text { Androstenedione }\end{array}$ & $\begin{array}{l}5 \alpha \text {-pregnane-3,20-dione } \\
\Delta^{4} \text {-Androstene-3,17,dione }\end{array}$ & t.l.c. I \\
\hline $\begin{array}{l}\text { 17a-Hydroxyprogesterone } \\
20 \alpha \text {-Dihydroprogesterone } \\
\text { Testosterone }\end{array}$ & 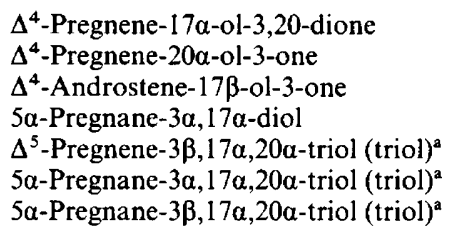 & t.l.c. $1 \& 2$ \\
\hline 17a-Hydroxypregnenolone & 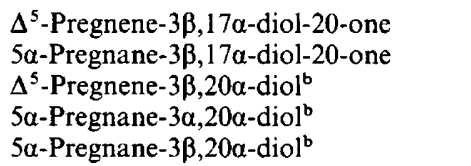 & t.l.c. $1,2 \& 3$ \\
\hline $\begin{array}{l}\text { Dehydroisoandrosterone } \\
\text { Isoandrosterone } \\
\text { Dihydrotestosterone }\end{array}$ & 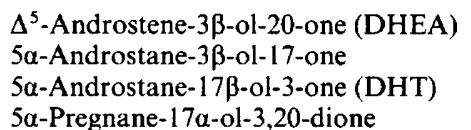 & $\begin{array}{l}\text { t.l.c. } 1 \& \\
\text { h.p.l.c. }\end{array}$ \\
\hline $\begin{array}{l}\text { Androsterone } \\
\text { Pregnenolone }\end{array}$ & 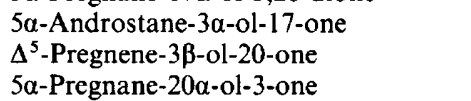 & \\
\hline Allopregnanolone & $\begin{array}{l}5 \alpha \text {-Pregnane- } 3 \beta \text {-ol-20-one } \\
5 \alpha \text {-Pregnane- } 3 \alpha \text {-ol-20-one }\end{array}$ & \\
\hline Progesterone & $\begin{array}{l}\Delta^{4} \text {-Pregnene-3,20-dione } \\
5 \alpha \text {-Androstane-3,17-dione }\end{array}$ & $\begin{array}{l}\text { t.l.c. } 1 \& \\
\text { h.p.l.c. }\end{array}$ \\
\hline $\begin{array}{l}\text { Androstenediol } \\
\text { Androstanediol }\end{array}$ & 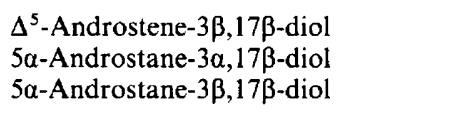 & $\begin{array}{l}\text { t.l.c. } 1,2 \\
\text { \& h.p.l.c. }\end{array}$ \\
\hline $\begin{array}{l}\text { Oestrone } \\
\text { Oestradiol } \\
\text { Oestriol }\end{array}$ & 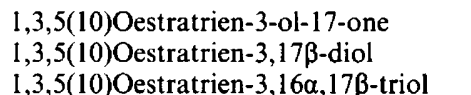 & t.l.c. 4 \\
\hline
\end{tabular}

*Steroids with the same superscript letter were not separated from each other.

†t.l.c. 1, chloroform:ether $(7: 1 \mathrm{v} / \mathrm{v})$; t.l.c. 2 , chloroform:methanol $(97: 3 \mathrm{v} / \mathrm{v})$; t.l.c. 3, chloroform: ether $(7: 1 \mathrm{v} / \mathrm{v}$ after acetylation); t.l.c. 4 , dichloromethane:ethyl acetate $(99: 1 \mathrm{v} / \mathrm{v}$ after acetylation).

substrate, $N=5$ ), demonstrating the presence of 17 -ketosteroid reductase activity. To determine whether aromatase activity was absent from the hpg ovary or whether it was present at very low levels, 10 ovaries were incubated together with $\left[{ }^{3} \mathrm{H}\right]$ androstenedione. Under these conditions very low levels of oestradiol were formed $(0 \cdot 17 \%$ of added substrate) which did recrystalize to a constant ${ }^{3} \mathrm{H} /{ }^{14} \mathrm{C}$ ratio. Only trace levels of oestrone were observed $(0.07 \%)$ which were too low to use for crystallization studies.

\section{Discussion}

The results described in this report have been summarized in Fig. 2 to show the major pathways of steroid metabolism which occur in the mouse ovary. Our results indicate that pregnenolone is mainly metabolized through progesterone and that the $\Delta^{5}$-pathway of $\mathrm{C}_{19}$ steroid production does not operate. The major progestagens formed are progesterone, at all ages, $5 \alpha$-pregnane-3 $\alpha$-ol-20one in the immature animal between 21 and 29 days and $20 \alpha$-dihydroprogesterone from 38 days. 
Table 2. Steroids formed during incubation of mouse ovaries with $\left[{ }^{3} \mathrm{H}\right]$ pregnenolone

\begin{tabular}{|c|c|c|c|c|c|c|}
\hline \multirow[b]{3}{*}{ Steroid } & \multicolumn{6}{|c|}{ Steroid formed as $\%$ of added $\left[{ }^{3} \mathrm{H}\right]$ pregnenolone } \\
\hline & \multicolumn{5}{|c|}{ Normal mice } & \multirow{2}{*}{$\begin{array}{l}\text { hpg mice } \\
(\mathrm{N}=4)\end{array}$} \\
\hline & $\begin{array}{c}7 \text { days } \\
(\mathrm{N}=9)\end{array}$ & $\begin{array}{l}21 \text { days } \\
(\mathrm{N}=5)\end{array}$ & $\begin{array}{l}29 \text { days } \\
(\mathrm{N}=6)\end{array}$ & $\begin{array}{l}38 \text { days } \\
(\mathrm{N}=8)\end{array}$ & $\begin{array}{l}60 \text { days } \\
(N=6)\end{array}$ & \\
\hline Progesterone & $\frac{18 \cdot 0}{5 \cdot 5} \pm$ & $\begin{array}{l}65.6 \pm \\
11.6\end{array}$ & $\begin{array}{r}49 \cdot 8 \\
5 \cdot 3\end{array}$ & $\begin{array}{l}50.9 \\
14.4\end{array} \pm$ & $\begin{array}{r}72 \cdot 0 \pm \\
8.0\end{array}$ & $\begin{array}{l}34 \cdot 1 \\
10 \cdot 7\end{array} \pm$ \\
\hline $5 \alpha$-Pregnane- 3,20 -dione & $\begin{array}{l}0.22 \pm \\
0.05\end{array}$ & $\begin{array}{l}1 \cdot 20 \pm \\
0 \cdot 35\end{array}$ & $\begin{array}{l}1.39 \pm \\
0 \cdot 32\end{array}$ & $\begin{array}{l}0.71 \pm \\
0.01\end{array}$ & $\begin{array}{l}0.37 \pm \\
0.06\end{array}$ & $\begin{array}{l}0 \cdot 64 \pm \\
0 \cdot 10\end{array}$ \\
\hline $5 \alpha$-Pregnane- $3 \alpha-o l-20$-one & $\begin{array}{l}1.06 \pm \\
0.52\end{array}$ & $\begin{array}{l}8 \cdot 60 \pm \\
2 \cdot 67\end{array}$ & $\begin{array}{l}6 \cdot 20 \pm \\
1.52\end{array}$ & $\begin{array}{l}2.61 \pm \\
1.0\end{array}$ & $\begin{array}{l}1.60 \pm \\
0.54\end{array}$ & $\begin{array}{l}1.59 \pm \\
0.47\end{array}$ \\
\hline Allopregnanolone & $\begin{array}{l}0.22 \pm \\
0.07\end{array}$ & $\begin{array}{l}5 \cdot 72 \pm \\
3 \cdot 64\end{array}$ & $\begin{array}{l}0 \cdot 72 \pm \\
0 \cdot 30\end{array}$ & $\begin{array}{l}1.03 \pm \\
0.01\end{array}$ & $\begin{array}{l}0.87 \pm \\
0.45\end{array}$ & $\begin{array}{l}0.17 \pm \\
0.07\end{array}$ \\
\hline 17 $\alpha$-Hydroxyprogesterone & $\begin{array}{l}0.62 \pm \\
0.25\end{array}$ & $\begin{array}{l}0.50 \pm \\
0.13\end{array}$ & $\begin{array}{l}1.76 \pm \\
0.85\end{array}$ & $\begin{array}{l}8.07 \pm \\
3.0\end{array}$ & $\begin{array}{l}2 \cdot 70 \pm \\
1.0\end{array}$ & $\begin{array}{l}0.68 \pm \\
0.22\end{array}$ \\
\hline $5 \alpha$-Pregnane- $3 \alpha, 17 \alpha$-diol-20-one & $\begin{array}{l}0 \cdot 18 \pm \\
0 \cdot 05\end{array}$ & $\begin{array}{l}0.50 \pm \\
0.08\end{array}$ & $\begin{array}{l}0 \cdot 46 \pm \\
0 \cdot 33\end{array}$ & $\begin{array}{l}1.64 \pm \\
0.01\end{array}$ & $\begin{array}{l}0.63 \pm \\
0.45\end{array}$ & - $^{*}$ \\
\hline 20a-Dihydroprogesterone & $\begin{array}{l}1.71 \pm \\
0.39\end{array}$ & $\begin{array}{l}1.77 \pm \\
0.66\end{array}$ & 一 $^{*}$ & $\begin{array}{l}6 \cdot 54 \pm \\
4 \cdot 0\end{array}$ & $\begin{array}{r}10.2 \\
3.0\end{array}$ & 一 $^{*}$ \\
\hline Androstenedione & $\begin{array}{l}0.87 \pm \\
0.14\end{array}$ & $\begin{array}{l}3.90 \pm \\
0.96\end{array}$ & $\begin{array}{l}5 \cdot 24 \pm \\
1 \cdot 71\end{array}$ & $\begin{array}{l}7.86 \pm \\
1.75\end{array}$ & $\begin{array}{l}2.06 \pm \\
1.0\end{array}$ & $\begin{array}{l}0.57 \pm \\
0 \cdot 10\end{array}$ \\
\hline Testosterone & $\begin{array}{l}0.34 \pm \\
0.13\end{array}$ & $\begin{array}{l}0.50 \pm \\
0.16\end{array}$ & $\begin{array}{l}0 \cdot 83 \pm \\
0.33\end{array}$ & $\begin{array}{l}3.91 \pm \\
0.94\end{array}$ & $\begin{array}{l}0.37 \pm \\
0.19\end{array}$ & - $^{*}$ \\
\hline Androstanediol & $\begin{array}{l}0.10 \pm \\
0.03\end{array}$ & 一 $^{*}$ & $\begin{array}{l}0 \cdot 35 \pm \\
0 \cdot 11\end{array}$ & $\begin{array}{l}0.89 \pm \\
0.19\end{array}$ & $\begin{array}{l}0.61 \pm \\
0.22\end{array}$ & 一 $^{*}$ \\
\hline
\end{tabular}

Values are mean \pm s.e.m. for the number of animals indicated (N).

*Not detectable.

Table 3. $\mathrm{C}_{18}$-steroids formed during incubation of mouse ovaries with $\left[{ }^{3} \mathrm{H}\right]$ androstenedione

\begin{tabular}{lcccccc}
\hline & \multicolumn{7}{c}{ Oestrogens formed as $\%$ of added $\left[{ }^{3} \mathrm{H}\right]$ androstenedione } \\
\cline { 2 - 6 } & \multicolumn{7}{c}{ Normal mice } & hpg mice \\
\cline { 2 - 6 } Steroid & 7 days & 21 days & 29 days & 38 days & 60 days & \\
\hline Oestradiol & $(\mathrm{N}=3)$ & $(\mathrm{N}=5)$ & $(\mathrm{N}=4)$ & $(\mathrm{N}=5)$ & $(\mathrm{N}=5)$ & $(\mathrm{N}=5)$ \\
Oestrone & $0.59 \pm 0.11$ & $0.69 \pm 0.07$ & $0.29 \pm 0.08$ & $1 \cdot 16 \pm 0.23$ & $0.48 \pm 0.26$ & $-^{*}$ \\
\hline
\end{tabular}

Values are mean \pm s.e.m. for the number of animals indicated (N).

*Not detectable.

Androstenedione was the major $\mathrm{C}_{19}$ steroid at all ages. From these results it is clear that the pattern of ovarian metabolism in the mouse during development differs from that in the rat, particularly in the production of $\mathrm{C}_{19}$ steroids. In the rat, accumulation of androstenedione and testosterone is very low or non-detectable during development (Karakawa et al., 1976; Uilenbroek et al., 1983), the major products being androsterone and androstanediol which show a peak of production around the first ovulation (Eckstein et al., 1970; Karakawa et al., 1976; Inaba et al., 1978; Suzuki et al., 1978; Uilenbroek et al., 1983). There was a peak in $5 \alpha$-reductase activity in the mouse ovary between 7 and 38 days judged by the accumulation of $5 \alpha$-reduced $C_{21}$ steroids. This was reflected, 


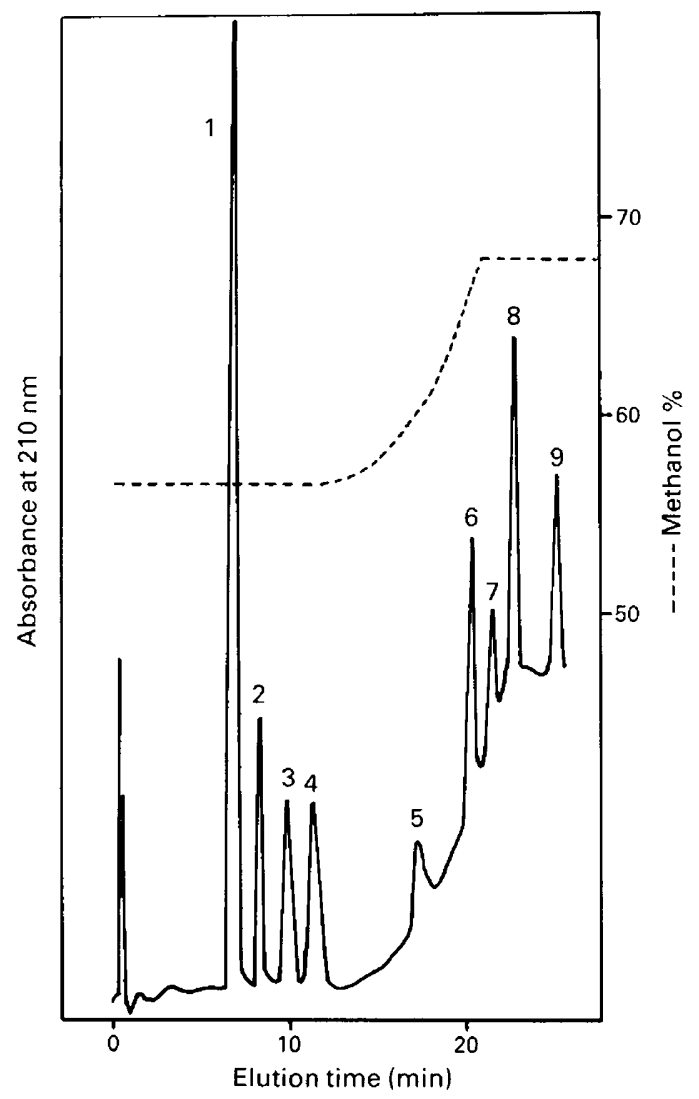

Fig. 1. Separation of steroids by h.p.l.c. as described in text. Steroids in order of elution are (1) DHEA, (2) isoandrosterone, (3) DHT, (4) 5 $\alpha$-pregnane-17 $\alpha$-ol-3,20-dione, (5) androsterone,

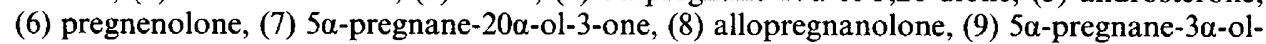
20-one.

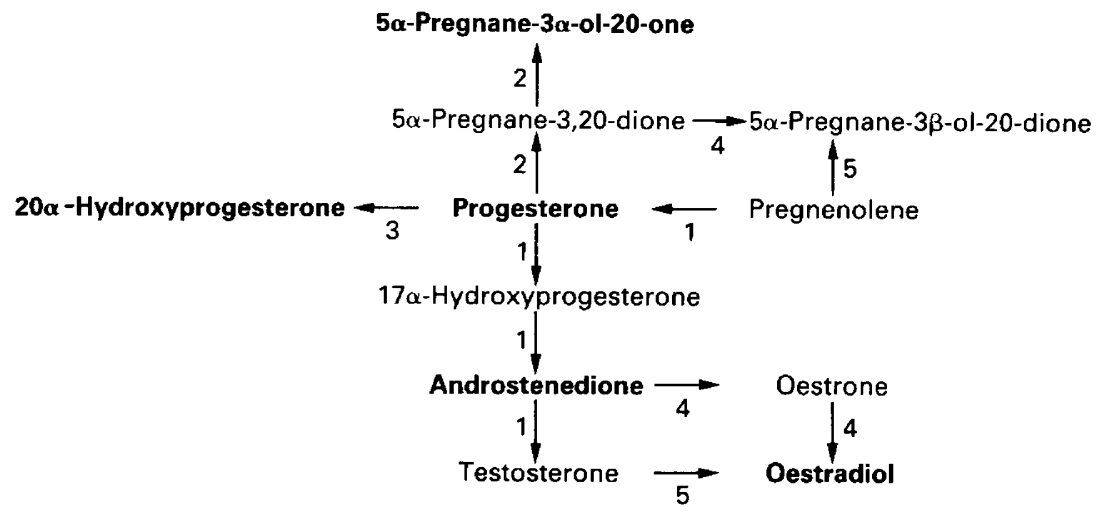

Fig. 2. Scheme of steroid metabolism in the mouse ovary during development. Major metabolites are indicated in bold type. (1) All ages; (2) predominantly immature; (3) predominantly adult; (4) presumed pathway; (5) pathway uncertain. 
however, in only low levels of androstanediol which peaked between 29 and 38 days, the time at which ovulation can first be observed in this strain of mouse (Halpin et al., 1986). Concentrations of androsterone were very low or undetectable at all times. The reason for the difference in steroid metabolism between these two species is not clear. It has been suggested that androsterone is synthesized in the rat via $5 \alpha$-pregnane- $3 \alpha$-ol-20-one and $5 \alpha$-pregnane-3 $\alpha, 17 \alpha$-diol-20-one (Karakawa et al., 1976; Inaba et al., 1978). High levels of 5a-pregnane-3-ol-20-one are formed in the mouse but it does not appear to act as a substrate for $\mathrm{C}_{17}-\mathrm{C}_{20}$ cleavage in this species.

In the rat $20 \alpha$-HSD is present in high concentrations in the regressing corpus luteum (Pupkin et al., 1966; Lahav et al., 1977). At 38 days of age corpora lutea are present in $50 \%$ of mice of the strain used in this study (Halpin et al., 1986) and this coincides with an increase in 20a-HSD activity which is sustained up to 60 days. It seems likely, therefore, that $20 \alpha$-HSD activity in the mouse ovary is also associated primarily with the corpus luteum. The presence of low activity before 29 days suggests that this enzyme must also be present in other tissue compartments of the ovary as it is in the rat (Eckstein et al., 1977).

At 7 days the ovaries of the mouse strain used in this study contain follicles at stages of development up to type 5a in which there are 3 layers of granulosa cells (Halpin et al., 1986). Development of interstitial tissue has not been examined in this strain although Quattropani (1973) has reported that in C57BL/6J mice interstitial cells can first be observed on Day 12. Theca interna cells first appear during follicular development when the oocyte is fully grown and 2 or 3 layers of granulosa cells are present (Peters, 1969). It seems likely, therefore, that the pregnenolone metabolism observed in the ovary at 7 days is due primarily to activity in the granulosa cells with low levels of $\mathrm{C}_{19}$ steroid production occurring in the developing theca. Significant aromatase activity is also present at 7 days and thus the necessary enzymes are present in the ovary at this stage to allow oestradiol synthesis from pregnenolone. By 21 and 29 days the ovaries are highly active in pregnenolone metabolism producing progesterone, $5 \alpha$-reduced $\mathrm{C}_{21}$ steroids and androgens (Fig. 2). This is associated with the development of antral follicles (type 7) at 21 days and preovulatory follicles at 29 days (Halpin et al., 1986). Evidence is now accumulating that ovarian follicles are gonadotrophin sensitive during the first week of life (Purandare et al., 1976; Terada et al., 1984; Halpin et al., 1986). This is associated with high plasma FSH concentrations in the mouse which then decline towards puberty (Halpin et al., 1986). It is possible, therefore, that changes in ovarian enzyme amounts during this time may also relate to the changes in plasma gonadotrophins in addition to follicular development. No marked differences in aromatase activity were observed in this study although the techniques used were not designed to measure the overall capacity of the tissue. There was no indication in the present studies that 16-keto-oestrone or 17-epioestriol were formed as reported by Vinson et al. (1963).

The hpg mouse offers a unique opportunity to study the function of GnRH-dependent gonadotrophin synthesis and secretion in gonadal development. The hpg mouse at the age used in this study contains follicles up to stage $5 \mathrm{~b}$ (fully grown oocyte with many granulosa cells but no follicular fluid) with occasional type 6 follicles (scattered areas of follicular fluid present) (Halpin et al., 1986). The pattern of pregnenolone metabolism was similar to that of 7-day animals demonstrating that $3 \beta$-HSD, $5 \alpha$-reductase, $C_{17}-C_{20}$ lyase and $17 \alpha$-hydroxylase are present. It is likely that these steroidogenic enzymes are under gonadotrophin control in the normal animal although it is clear from this study that activity may be expressed in the absence of gonadotrophin stimulation.

The ovaries of hpg mice contain 17-ketosteroid reductase (indicated using $\left[{ }^{3} \mathrm{H}\right]$ androstenedione as substrate) although the activity per ovary is markedly reduced compared to that of normal mice at any age studied. In addition, it is clear that $20 \alpha-\mathrm{HSD}$ and aromatase are present at only very low levels or are absent in the hpg ovary. It is possible that levels of these enzymes are normal in immature hpg animals and that activity subsequently declines. Whether gonadotrophins are required for initial expression of these enzymes will require further study but it is clear that gonadotrophin stimulation is required during development for normal expression of these enzymes. The results described here agree with the studies of Kraiem \& Samuels (1974) who demonstrated that 
the activities of $20 \alpha$-HSD and aromatase are increased by gonadotrophins in the 25-day mouse ovary. The lack of aromatase activity in the $h p g$ mouse ovary probably contributes to the inability of these follicles to develop to the antral phase. The data from the hpg mouse also suggest, however, that follicles can develop to the end of the pre-antral stage in the absence of gonadotrophins or ovarian oestrogen stimulation.

M.A.M. was supported by the British council. We thank Dr H. M. Charlton for providing breeding stock and adult hypogonadal mice for use in these studies.

\section{References}

Cattanach, B.M., Iddon, C.A., Charlton, H.M., Chiappa, S.A. \& Fink, G. (1977) Gonadotrophin releasing hormone deficiency in a mutant mouse with hypogonadism. Nature, Lond. 269, 338-340.

Cohen, J., Dore, C., Robaire, B. \& Ruf, K.B. (1984) Plasma concentrations of free $5 \alpha$-androstane- $3 \alpha, 17 \beta$ diol and related gonadal steroids during spontaneous and induced sexual maturation in the female rat. Biol. Reprod. 30, 105-111.

Eckstein, B. \& Ravid, R. (1979) Changes in pathways of steroid production taking place in the rat ovary around the time of first ovulation. J. Steroid Biochem. 8, 213-216.

Eckstein, B., Mechoulam, R. \& Burstein, S.H. (1970) Identification of $5 \alpha$-androstane- $3 \alpha, 17 \beta$-diol as a principal metabolite of pregnenolone in the rat ovary at onset of puberty. Nature, Lond. 228, 866-868.

Eckstein, B., Lerner, N. \& Yehud, S. (1976) Pre-ovulatory changes in steroidogenesis in ovaries from immature rats treated with pregnant mare serum gonadotrophin. J. Endocr. 70, 485-490.

Eckstein, B., Raanan, M., Lerner, N., Cohen, S. \& Nimrod, A. (1977) The appearance of $20 \alpha$ hydroxysteroid dehydrogenase activity in preovulatory follicles of immature rats treated with pregnant mare serum gonadotrophin. J. Steroid Biochem. 8, $213-216$.

Halpin, D.M.G., Jones, A., Fink, G. \& Charlton, H.M. (1986) Post-natal ovarian follicle development in hypogonadal $(h p g)$ and normal mice and associated changes in the hypothalamic-pituitary ovarian axis. J. Reprod. Fert. 77, 287-296.

Hutchison, J.B., Steimer, T. \& Duncan, R.L. (1981) Behavioural action of androgen in the dove: effects of long term castration on response specificity and brain aromatization. J. Endocr. 90, 167-178.

Inaba, T., Imori, T. \& Matsumoto, K. (1978) Formation of $5 \alpha$-reduced $\mathrm{C} 19$-steroids from progesterone in vivo by $5 \alpha$-reduced pathways in immature rat ovaries. $J$. Steroid Biochem. 9, 1105-1110.

Karakawa, T., Kurachi, K., Aono, T. \& Matsumoto, K. (1976) Formation of $5 \alpha$-reduced C-19 steroids from progesterone in vitro by a pathway through $5 a-$ reduced C-21 steroids in ovaries of late prepubertal rats. Endocrinology 98, 571-579.
Kraiem, Z. and Samuels, L.T. (1974) The influence of FSH and FSH + LH on steroidogenic enzymes in the immature mouse ovary. Endocrinology 95, 660-668.

Lahav, M., Lamprecht, S.A., Amsterdam, A. \& Lindner, H.R. (1977) Suppression of $20 \alpha$ hydroxysteroid dehydrogenase activity in cultured rat luteal cells by prolactin. Molec. cell. Endocr. 6, 293-302.

Milewich, L., George, F.W. \& Wilson, J.D. (1977) Estrogen formation by the ovary of the rabbit embryo. Endocrinology 100, 187-196.

O'Shaughnessy, P.J., Wong, K.-L. \& Payne, A.H. (1981) Differential steroidogenic enzyme activities in different populations of rat Leydig cells. Endocrinology 109, 1061-1066.

Peters, H. (1969) The development of the mouse ovary from birth to maturity. Acta endocr., Copenh. 62, 98-116.

Pupkin, M., Bratt, H., Weisz, J., Lloyd, C.W.\& Balough, K. (1966) Dehydrogenase in the rat ovary. I. A histochemical study of $\Delta^{5}-3 \beta$ - and $20 \alpha$ hydroxysteroid dehydrogenases and enzymes of carbohydrate oxidation during the estrous cycle. Endocrinology 79, 316-327.

Purandare, T.V., Munshi, S.R. \& Rao, S.S. (1976) Effect of antisera to gonadotrophins on follicular development and fertility of mice. Biol. Reprod. 15, 311-320.

Quattropani, S.L. (1973) Morphogenesis of the ovarian interstitial tissue in the neonatal mouse. Anat. Rec. $177,569-584$.

Suzuki, K., Kawakura, K. \& Tamaoki, B.I. (1978) Effect of pregnant mare's serum gonadotropin on the activities of $\tau^{4}-5 \alpha$-reductase, aromatase and other enzymes in the ovaries of immature rats. Endocrinology 102, 1595-1605.

Terada, N., Kuroda, H., Namika, M., Kitamura, Y. \& Matsumoto, K. (1984) Augmentation of aromatase activity by FSH in ovaries of fetal and neonatal mice in organ culture. J. Steroid Biochem. 20, 741-745.

Uilenbroek, J.T.J., Woutersen, P.J.A. \& van der Linden, R. (1983) Steroid production in vitro by rat ovaries during sexual maturation. J. Endocr. 99, 469-475.

Vinson, G.P., Norymberski, J.K. \& Chester Jones, I. (1963) The conversion of progesterone into oestrogens by the mouse ovary. J. Endocr. 25, 557-558.

Received 30 July 1987 